\title{
BILINGUALISM OF LANGUAGE LEARNING IN ISLAMIC SCHOOL (ETHNOGRAPHIC RESEARCH IN DAARUL RAHMAN ISLAMIC SCHOOL I, SOUTH JAKARTA)
}

\author{
Fitriyani ${ }^{1}$, Yumna Rasyid ${ }^{2}$ \\ fitri.yani_pb13s2@mahasiswa.unj.ac.id ${ }^{1}$ yumna.rasyid@unj.ac.id ${ }^{2}$
}

\begin{abstract}
The aims of this research are to examine deeply the process of bilingualism language learning, the environment of language learning bilingualism, the teacher's involvement of teachers of bilingualism language learning, the students' participation in the bilingualism language learning and the evaluation of bilingualism language learning in Daarul Rahman I Islamic Schools, South Jakarta. This a qualitative research with the ethnographic approach. The informants in this study are agelevel of High School students. The method of data collection is done by observation, interview and documentation. The results of this study shows that the learning process of Arabic language and English in the neighborhood of Daarul Rahman I Islamic School is a tradition experiences the development of suitable students and science in the millennial. In addition, the environment of language learning is very conducive. The involvement of teachers in language learning rise learning culture which is integrated and student-centered. While, the involvement of students in language learning belongs to communicative learning and culture rise to active and disciplined in speaking. Evaluation in language learning includes written and unwritten test, focuses upon four languages proficiency.
\end{abstract}

Keywords: Bilingualism, Islamic student, Daarul Rahman Islamic school I

A foreign language is a language other than the native language (mother tongue) and national language (second language). There are some forms of foreign languages learnt at school such as English and the Arabic.

School as an official education institution, helps provide all facilities and environment of learning a foreign language. Implementation of the learning program at a school with an introduction to foreign language gets various obstacles because of the position of foreign language in Indonesia.

Other popular foreign language is Arabic. Arabic becomes the official subjects in school based on the religion of Islam. In addition, the closeness of Indonesian community's culture, caused by the majority of religion adherents are Muslim, making Arabic needs to be learned earlier. It can be seen by the growth of the non-formal educational institutions before the establishment of the school in the middle society, which is very significant.

The institution of Islamic boarding school divided by two classifications i.e. modern and salafi (traditional) boarding school. Irfan Paturohman in his research entitled "The Role of boarding school's Education in the Improvement of the diversity's condition in its environment", Journal of Tarbawi Vol. 1 Number 1 March 2012, states that the function of the boarding schools consists of three things. First, it is as an educational institution. Second, it is as a social institution and the third as religious broadcasters. This is relevant to this research, which focuses on the function of boarding school as educational institution, especially related to the development of second language learning as an introduction to apply in it.

Learning trough bilingual done gradually until the students understand the meaning of sentences in that language. It needs technical instructions on how bilingual learning in it. The lack of sources can be used as a reference model to produce a bilingual learning interpretation of bilingual 
learning according their understanding of each. But before the application of the bilingually system, boarding schools have several stages in the process of the development of the learning system.

The application of foreign language applied by the boarding school already has a developed education system orientation. Language learning in some boarding schools already includes Arabic and English in it as a daily language.

Daarul Rahman boarding school is the only boarding school in Jakarta granted as muadalah. The boarding school has got many achievements since it was built such as being a public champion of reading yellow bible and well presenting for Arabic and English speech competition in regional and national level.

The implementation of its education uses an integrated system between the educational systems of Darussalam modern boarding school or commonly called the Gontor and Salafi (traditional). Gontor is the originator of muadalah system and used as the main reference by all muadalah boarding schools. The combination of its educational curricula makes the output generated by the intelligence of its students growing and able to adjust with the aim of education in Indonesia.

In addition, this boarding school fulfills the criteria of the research, i.e. prioritizes the mastering of two foreign languages, Arabic and English and the boarding schools graduation can adjust with the demands of the world of education when they want to continue to the college. As for the research location is reachable, both by researchers as well as the students.

Daarul Rahman boarding school does not only focus on the use of Arabic as the daily language, but also English become the official language must be used daily in the environment of boarding school.

Every Thursday-Saturday the students are required to use Arabic language and on Sunday they collaborate of two languages or one of them. The language obligation is carried out during 24 hours no matter where the students are. Relevant to the research conducted by Wulan Supiani, entitled The Effect of the Use of Bilingual Direct Method in communicating In a Modern Cottage Darussalam Gontor Princess 4 Lamomea Village Sub District South Wowoni Island Konda, Journal Communications UHO, Vol 2 No. 2, 2017, with findings in the field there are some linguistic activities such as language week, daily conversation, speech contests, drama, learning in the classroom using the Arabic language or English, nice Friday, miss language and evaluation.

The focus of this research is Bilingualism of language learning in Daarul Rahman I Islamic School, South Jakarta. While the subfocus are as follow (1)Bilingualism process of language learning in the environment of Daarul Rahman I, South Jakarta, (2)Environmental bilingualism language learning in Daarul Rahman I, South Jakarta (3)Involvement of teachers in bilingualism language learning in Daarul Rahman I, South Jakarta, (4)The participation of students in bilingualism language learning in Daarul Rahman I, South Jakarta, (5)Bilingualism evaluation of language learning in Daarul Rahman I, South Jakarta.

First language gaining occurs in children naturally, whereas second language gaining happen intentionally through formal and informal learning. Ahmad Habibi martyr, in his journal titled Arabic as a second language (Theoretical Studies of the Arabic language acquisition In Non-Native Students), Arabiyat: Journal of Arabic Education and Arabic language (2) (1), 2015, stating things that are relevant to this theory refers to two great theories i.e. behavioristic and mentality theory as a foundation for the process of second language achievement.

Discussion of bilingualism always relates to some conceptual definitions of several related theories. The first theory is second language gaining, intentionally through formal and informal studies. Further language learning theory which has two main runways, namely the linguistic Foundation and psychology.

Next is the theory of bilingualism, the psychological condition of someone who is capable to use two languages in social communication. As for the process of learning a language in the concept of bilingualism, there are some models commonly used in the implementation of bilingual education, i.e. the transitional bilingual education and the maintenance of bilingual education. 
As for the language learning environment consists of (1) the social environment, (2) personal environment (3) the natural environment, and (4) the cultural environment. Learning environment can be divided into two kinds of learning environment, an environment in a classroom or a formal learning environment and the environment outside the classroom or informal environment.

The teacher is a private key (key person) in the classroom, due to the immense impact to the behavior and learning of students, who have a tendency to imitate and identify.

Each study has evaluation. The student assessment in a semester is divided by two things, the formative and summative evaluation. In the category of language learning language tests is divided into four groups, namely 1) test proficiency, 2), (3) placement test) diagnostic tests, and 4) test achievement.

\section{METHOD}

The researcher uses a qualitative method with ethnographic approach. Ethnographic approach, with the procedure are as follows (a) defines a research problem, (b) formulate a hypothesis, (c) making operational definitions, (d) designed a research instrument, (e) collect data, analyze the data (f), (g) describe conclusions, (h) to report results. Here in after refer to the model analysis of Spradley, consisting of four stages of analysis, i.e. the domain analysis, analysis of the taxonomy, the analysis of the components and the analysis of the theme.

\section{RESULT AND DISCUSSION}

The process of learning Arabic and English in the neighbourhood of Daarul Rahman I split into two categories. Formal language learning, namely in the form of the subject matter which is given periodically in class, scheduled for 5-7 days. For the duration of the lesson the Arabic language and the following English derivative related subjects, given time for 45 minutes to learn it.

Informal language learning belongs to muhadasah weekly. Muhadasah evening before evening learning, every Monday and Friday for 45 minutes, which is supervised by the administrators of language students. There is also muhadasah morning, every Tuesday and Saturday is also supervised by the member part of language students.

In language learning environment, it finds some things in the language learning environment that exists in Daarul Rahman 1. (1) In every end of the semester, it always evaluates student's language proficiency, for a particular program of remedial or enrichment, adjust with the level of achievement of the students. (2) before the beginning of the lesson, the teacher started with interesting ask students with experiences in asking her to speak, both on a personal as well as individuals. (3) In the learning in the classroom and outside the classroom, at the end of the discussion of certain material, the students were asked to write down the back or interpret the readings, and then answer a few questions related to these readings.

Learning environment in the classroom is a learning environment conditioned by the teachers in classrooms tailored to the learning objectives of the program and boarding schools. The language learning environment outside the classroom is more dominated by the student responsibility in linguistic, i.e. Kismul Tarkih.

In accordance with the observations in the field, the function of the teacher as the controller of the learning process is clearly visible, for instance, in the activities of muhadsah, muhadoroh and rote mufrodat. Teachers also guide the students to speak better in an environment of boarding schools. Teachers also always give morale on the students, as the driving motivation intern students to continue to try and improve the language in case of confusion.

The main object of foreign language learning in an environment of boarding schools is all students from grade 1 to grade 6. The students that serve as active learners who use the Arabic language and the language of the United Kingdom actively and scheduled from boarding schools or because of other special provisions. 
The evaluation of the learning in the classroom and outside the classroom is given in written form, such as Deuteronomy formative/daily, weekend test and final exam. In addition there is also an evaluation in the form of a written test as not speaking and portfolio. The assessment itself is made in written form. That is generally in the form of a multiple choice question, the stuffing and the explanation given on the students any discussion material is completed.

\section{CONCLUSION}

It concludes that the process of learning Arabic language and English in the neighbourhood of Daarul Rahman I goes well and effectively. As for inferred specifically as follows.

The process of learning Arabic and English in the neighbourhood of Daarul Rahman I split into two categories. Formal language learning, namely in the form of the subject matter which is given periodically in class, scheduled for 5 days with details of each day of each lesson Arabic and the English as the following fractions as given a duration of 45 minutes to learn it.

Several things are exist in the environment of language learning at Daarul Rahman 1. (1) Every end of the semester always evaluates language proficiency of students, for a specified program of remedial or enrichment, adjust with the level of achievement of the students. (2) Before starts the lesson, the teacher opens with interesting question to students so stimulates them to speak on a personal as well as individuals.

The other teacher's role can be seen when performing evaluation on participants of his protégé such as in the activities of muhadsah, muhadoroh and rote mufrodat. Teachers also guide the students to speak better in the environment of boarding schools. Teachers also always give morale on the students, as the driving motivation intern students to continue trying and improving the language in case of errors

The students enjoy the use of Arabic or English interchangeably, especially the students of class 2-6 which is a lot more to absorb foreign language vocabulary. When realizing the errors of language, they no longer hesitate to ask teachers, teacher language nor the stewards section. However, the dictionary belongs to each student's searching.

Evaluation in language learning environment of Daarul Rahman I, through some procedures, namely test, oral tests, and tests include: (1) the observation, (2) the scale of assessments (rating scale), (3) list (check list). As for the evaluation of four language proficiency, i.e. listening skills focuses on two types of tests, i.e. tests by recording and test in the form of questioning or interview. To finesse the speech, done differently dependent level of skills already acquired the learner. Evaluation of proficiency reading, among others, by using the correct form-false, multiple choice, sentence is complete, making a summary or conclusion, cloze test, C-test and others. Finally, tests that accommodate the most complex evaluation for writing proficiency is a test in the shape of a wreath.

Researcher needs to put of several recommendations related to the formulation of the problem in this research, which is in the process of learning the Arabic and English in the neighbourhood of Daarul Rahman I that is a tradition surely it will experience the development of students ' needs and the development of appropriate knowledge. So the enrichment of teachers outside the neighbourhood of boarding schools for self's development needs to be done.

Next, in language learning's environment that awakens through linguistic cultures is a situation that needs to be appreciated; it can be directed into environmentally speaking fusha in formal school hours and environment' speaking amiyah outside formal school hours.

As for the involvement of teachers in language learning, by familiarizing the students to read and to dig the theme as well as writing it down, the power of imagination and insight will be increasingly opened, students will find things that are new, so it is not monotonous in learning in a rigid material. Next, the participation of students in language learning can be found in language learning activities. Students should be directed to like reading a variety of literature in the foreign 
language, either through work group, individual and placed into one of the points the punishment for their violation of known languages and improve the ability to write.

Last, the evaluation in language learning is already quite sufficient. Consistency in every evaluation and enrichment based on final results met language learning objectives desired by the boarding schools and by individuals.

\section{REFERENCE}

Arsyad, Azhar. Bahasa Arab dan Metode Pengajarannya. Yogyakarta: Pustaka Pelajar. 2004 Ahmad, Izzan. Metodologi Pembelajaran Bahasa Arab, Cet. II. Bandung: Humaniora. 2007 Bialystok,E. Bilingualism in Development, Language, Literacy and Cognition. New York: Cambridge University Pres. 2001

C. Baker. Foundation of Bilingual Education and Bilingualism. Multilingual Matters. 2006

Chaer, Abdul. Psikolinguistik; Kajian Teoretik. Jakarta: Rineka Cipta. 2009.

Chaer, Abdul dan Leonie Agustina. Sosiolinguistik Perkenalan Awal. Jakarta: Rineka Cipta. 2010

Chin, NgBee, and Wigglesworth, G. Bilingualism: an Advanced resource book. Abigdon: Routledge. 2007

Emzir. Metodologi Penelitian Pendidikan Kuantitatif dan Kualitatif. Jakarta: Raja Grafindo. 2013

Fachrurrozi, Aziz dan Erta Mahyuddin. Pembelajaran Bahasa Asing Metode Tradisional dan Kontemporer. Jakarta: Bania Publishing. 2010

Garcia, Eugene E. Billingual Education. 2008

Grimshaw, Anna, The Ethnographer's Eye: Ways to Seeing in Modern Anthropology, Cambridge: Cambridge University Press, 2001

Harlow Essex: Pearson Education Limited. 2001

Iskandarwassid dan Dadang Sunendar. Strategi Pembelajaran Bahasa. Bandung: Remaja Rosdakarya. 2013

Irwanto. Psikologi Umum; Teori Belajar. Jakarta: Prenhallindo. 2002

Jihad, Asep dan Abdul Haris. Evaluasi Pembelajaran. Yogyakarta: Multi Pressindo. 2008

Nunan, David.Task Based Language Teaching.Cambridge: Cambridge University Press. 2004

Nurbayan,Yayan. Metodologi Pembelajaran Bahasa Arab. Bandung : Zein Al Bayan. 2008

Oemar Hamalik, Proses Belajar Mengajar. Jakarta : Bumi Aksara,2013

Setiadi, Bambang. Metode Penelitian Untuk Pengajaran Bahasa Asing. Yogyakarta: Graha Ilmu. 2006

Spradley, James. Metode Etnografi. Yogyakarta: Tiara Wacana Yogya. 2007

-Participan Observation. New York: Holt, Rinehar and Winston. 2008

Wei, L. The Bilingualism Reader. London: Routledge. 2000 